\title{
Comparative Study of Gamma Radiation and Prednisolone Induced Submandibular Salivary Gland Oxidative Damage
}

\author{
Salwa Farid Ahmed \\ Health Radiation Research Department, National Centre for Radiation Research and \\ Technology (NCRRT), Atomic Energy Authority (AEA), Cairo, Egypt.
}

\begin{abstract}
$\mathbf{T}$ HE MOST pronounced salivary dysfunction occurs in patients taking medications that interfere with salivary secretory processes and those who have received therapeutic irradiation. The aim of the present study is to investigate the effect of gamma radiation and prednisolone treatment on submandibular salivary glands. Forty eight female Albino rats were divided into four groups. Group C serves as control; group P was treated with Depo-Medrol; group $\mathrm{R}$ was exposed to whole body gamma radiation and group $\mathrm{PR}$ is similar to the previous one in addition, it has received Depo-Medrol. The submandibular glands were obtained three and seven days post-irradiation. Gamma-irradiation induced vacuolization of all gland compartments, acinar atrophy and degeneration of striated ducts and granular convoluted tubules. In group P, the acini lost their outline with shrinkage of some acini. The striated ducts represented variable degree of degeneration, lumen narrowing. Nuclear fragmentation was detected in duct and granular convoluted tubule cells. All previously mentioned manifestations were detected in an exaggerated manner in group PR. Thetotal glutathione content and glutathione-peroxidase activity significantly decreased in all experimental groups. Activity of superoxide dismutase significantly decreased in R group, while it was not affected in $\mathrm{P}$ and PR groups. Total protein content significantly decreased in $\mathrm{R}$ group in contrast to $\mathrm{P}$ group, where a significant increase was observed. In PR group, it was not affected at day 3 , but it significantly decreased at day 7. In conclusion, either gamma radiation orprednisolone induced submandibular salivary gland oxidative stress; however, their combined use ameliorated, to some extent, gamma radiation induced oxidative damage.
\end{abstract}

Keywords: Gamma radiation, Salivary gland, Prednisolone, Protein, Glutathione.

\section{Introduction}

Many systemic diseases are associated with alterations in salivary output. The most pronounced salivary dysfunction occurs in patients taking medications that interfere with salivary secretory processes (Nederfors, 1996), those who have received therapeutic irradiation to eradicate head and neck malignancies (Stone et al., 2003) and patients with Sjögren's syndrome (Atkinson \& $\mathrm{Wu}, 1994)$.

Radiation treatment of oral and pharyngeal malignancies typically includes salivary tissue within the field. At doses above 50Gy, patients can lose all salivary function if the salivary glands are totally within the radiation field (O'Connell et al., 1999). Salivary hypofunction after gland irradiation is very difficult to treat, as salivary parenchyma within the radiation field is damaged permanently (Guchelaar et al., 1997). Irradiation of submandibular glands induced minimal cell vacuolization and minimal to moderate loss of acinar structure. In addition, moderate cell necrosis and ductal damage could be detected (Şimşek et al., 2012). The reasons for the extreme radiosensitivity of human salivary tissues remain undefined (Adelstein et al., 2000).

Synthetic glucocorticoids were the choice for treatment of many systemic inflammatory and autoimmune disorders due to their antiinflammatory and immunosuppressive effects (Busillo et al., 2013 and Bazsó et al., 2015). However, their use, especially for a long duration or at high doses, may be associated with the 
emergence of a great number of side effects including diabetes, hypertension, osteoporosis and growth retardation (Schäcke et al., 2002). Administration of glucocorticoids may worsen the course of existing stress condition such as increased Andriamycin potency of reactive oxygen species production (McIntosh \& Sapolsky, 1996) andamyloid $\beta$-peptide induction of lipid peroxidation (Goodman et al., 1996). Moreover, glucocorticoids inhibited the production of antioxidant enzymes in response to elevated reactive oxygen species (McIntosh et al., 1998 a). The present study examined the hazardous effect of gamma radiation and prednisolonealone and in combination on submandibular salivary gland morphology, function and antioxidant status.

\section{Experimental}

\section{Animals}

Forty eight non-pregnant female Albino rats weighing 250-300g were fed with semi purified diet and water ad libitum for 10 days before the start of the experiment. They were maintained at a standard condition of $24^{\circ} \mathrm{C} \pm 5^{\circ} \mathrm{C}$. The animals were divided into 4 groups, 12 animals each. The first group $\mathrm{C}$ was used as control (no radiation exposure or prednisolone treatment). The second group $\mathrm{R}$ was exposed to a single dose of $6 \mathrm{~Gy}$ gamma radiation. The third group $\mathrm{P}$ treated with prednisolone. The fourth group PR represented the combination group where the rats were irradiated then treated with prednisolone. The animals were sacrificed 3 and 7 days post- irradiation. This study was approved to be carried out by the Committee of Scientific Ethics at of Faculty of pharmacy, Al-Azhar University, Egypt, following the guidelines of for animal use.The animals use was according to the rules and regulations of the animal experimental studies approved by the ethical committee including their facilities diet and method of sacrificing.

\section{Radiation exposure}

Rats in groups R and PR were exposed to a whole body single dose (6Gy) of gamma radiation at a dose rate of $0.48 \mathrm{~Gy} / \mathrm{min}$. Irradiation was performed at the National Centre for Radiation Research and Technology (NCRRT), Cairo, Egypt, using 137 Cesium Gamma Cell 40.

\section{Prednisolone treatment}

Rats in groups $\mathrm{P}$ and $\mathrm{PR}$ were injected subcutaneously with Depo-Medrol (Methyl prednisolone acetate) at a dose of $7 \mathrm{mg} / \mathrm{kg}$ body weight once a week for 8 weeks.

\section{Histological investigation and biochemical analyses \\ After sacrificing, the submandibular glands} were dissected and weighted in grams. The right glands were fixed in $10 \%$ formalin, processed for paraffin embedding and stained with hematoxylin-eosin for histological analysis. The left submandibular glands were weighed and homogenized $(10 \%)$ in chilled $50 \mathrm{mmol} / \mathrm{L}$ phosphate buffered saline ( $\mathrm{pH} 7.4)$, centrifuged at $1200 \mathrm{~g}$, at $4^{\circ} \mathrm{C}$ for $15 \mathrm{~min}$, using universal centrifuge (16R, Germany), then the supernatants were used for the determination of total glutathione (GSH), glutathione-peroxidase (GPx), superoxide dismutase (SOD) and total protein content. GSH content was measured according to Beutler (1963) using DTNB and was expressed as $\mathrm{mg} / \mathrm{g}$ wet tissue. GPx activity was measured according to Rotruck et al. (1973)and was expressed as $\mu$ Mof GSH oxidized/g wet tissue/min. Antioxidant enzymes activity of SOD activity was determined according to Nishikimi et al. (1972). The enzyme activity was expressed as U/g wet tissue. The total protein content was determined by Biuret method according to Henry (1974).

\section{Statistical analysis}

The results were expressed as means \pm S.D. Data analysis was performed by one- way analysis of variance (ANOVA) using Statgraphics XVII. Post hoc Tukey, a significant difference analysis was used to determine significant differences among the groups. Values of $\mathrm{P} \leq 0.05$ were considered statistically significant.

\section{$\underline{\text { Results }}$}

\section{Submandibular gland weight}

The submandibular glands of $\mathrm{R}$ and $\mathrm{PR}$ groups expressed a significantly lower weight as compared to the control one at three and seven days post-irradiation $(\mathrm{P}<0.05)$. There was no significant difference in submandibular gland weight of $\mathrm{C}$ and $\mathrm{P}$ groups all over the experimental period $(\mathrm{P}>0.05)$. At three days post-irradiation, submandibular glands of $\mathrm{P}$ and $\mathrm{PR}$ groups weighed significantly more than those of $\mathrm{R}$ group $(\mathrm{P}<0.05)$. However, at day seven only those of $\mathrm{P}$ group weighed significantly more than glands of $\mathrm{R}$ group $(\mathrm{P}<0.05)$ (Fig. 1). 


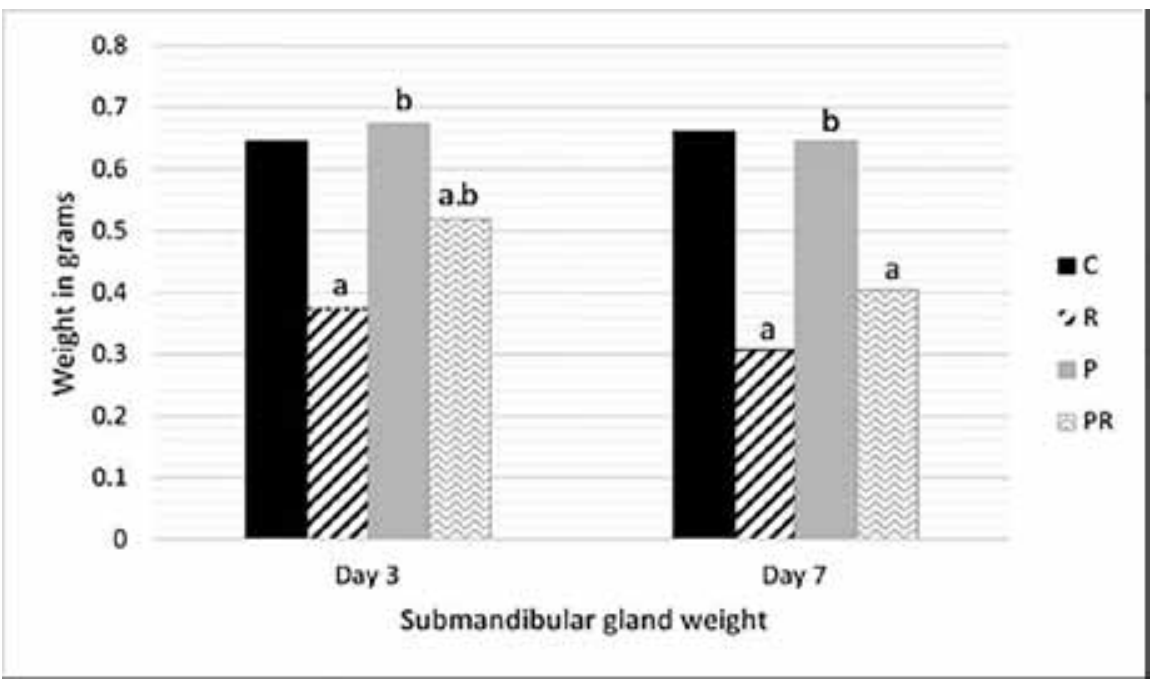

Fig. 1. Submandibular glands weight of different studied groups all over the experimental period [ ${ }^{\mathrm{a}}$ means significant difference as compared to $\mathrm{C}$ group and ${ }^{\mathrm{b}}$ means significant difference as compared to $\mathrm{R}$ group].

\section{Histological examination}

The control submandibular gland consisted of connective tissue stroma and parenchyma. The serous acini consisted of pyramidal cells with ovoid deeply basophilic nuclei. The mucous acini appeared as small discrete widely distributed islands among the serous acini. The intercalated ducts were composed of low cuboidal cells with centrally located rounded nuclei. The cells of striated ducts were columnar with pale centrally located nuclei and basal striation. The granular convoluted tubules were consisted of cuboidal cells with nuclei located at the basal third and expressed deeply acidophilic granules. The connective tissue septae were associated with some vascular elements including veins, arterial and neural components (Fig. 2 A).

Examination of submandibular gland of $\mathrm{R}$ group three days post-irradiation revealed loss of the normal outline and architecture, mild vacuolization and slight atrophy of some acini. The intercalated duct and some striated ducts were almost normal while other striated ducts showed degenerative changes with mild vacuolization. Most of the granular convoluted tubules appeared normal while the others revealed vacuolization (Fig. 2 B). Seven days post-irradiation, the gland showed obvious loss of acinar outline and architecture with massive vacuolization. Most of striated ducts exhibited a variable degree of degenerative changes with a clear vacuolization, while only few ducts remain intact. The granular convoluted tubules showed degenerative changes with degranulation (Fig. 2 E).
Three days post-irradiation, prednisolone treated submandibular gland revealed normal sized acini with loss of their outline. The nuclei were normal in size and shape. The morphological changes of the striated ducts were represented by degeneration of some ductal cells, nuclear fragmentation, narrowing of some lumens and the presence of space around some ducts. Some granular convoluted tubules showed variable degrees of degeneration while most of them were normal (Fig. 2 C). Seven days post-irradiation, the previous manifestations were in progress where the acinar cells showed an ill-defined cellular outline with shrinkage of some acini. Most of the striated ducts exhibited a massive degeneration with nuclear fragmentation and narrowing of the lumens or even complete obliteration. The granular convoluted tubules were degenerated with fragmentation of their nuclei (Fig. 2 F).

The submandibular glands of combination group (PR) showed different morphological changes. Three days post-irradiation, some of the serous acini had normal outline and architecture while the other lost both of them. The most obvious change was the presence of massive acinar intracytoplasmic vacuoles all over the gland. The striated ducts had manifestations represented by ductal cell vacuolization and degeneration that may lead to complete duct degeneration. Nuclear fragmentation could be detected in many ductal cells. Almost all granular convoluted tubules showed degenerative changes with nuclear fragmentation (Fig. 2 D). Seven days post-irradiation, the acini restored, to some extent, their normal architecture while 
their outline still lost and the acinar vacuolization was decreased. The striated ducts were severely affected as most of them exhibited a massive
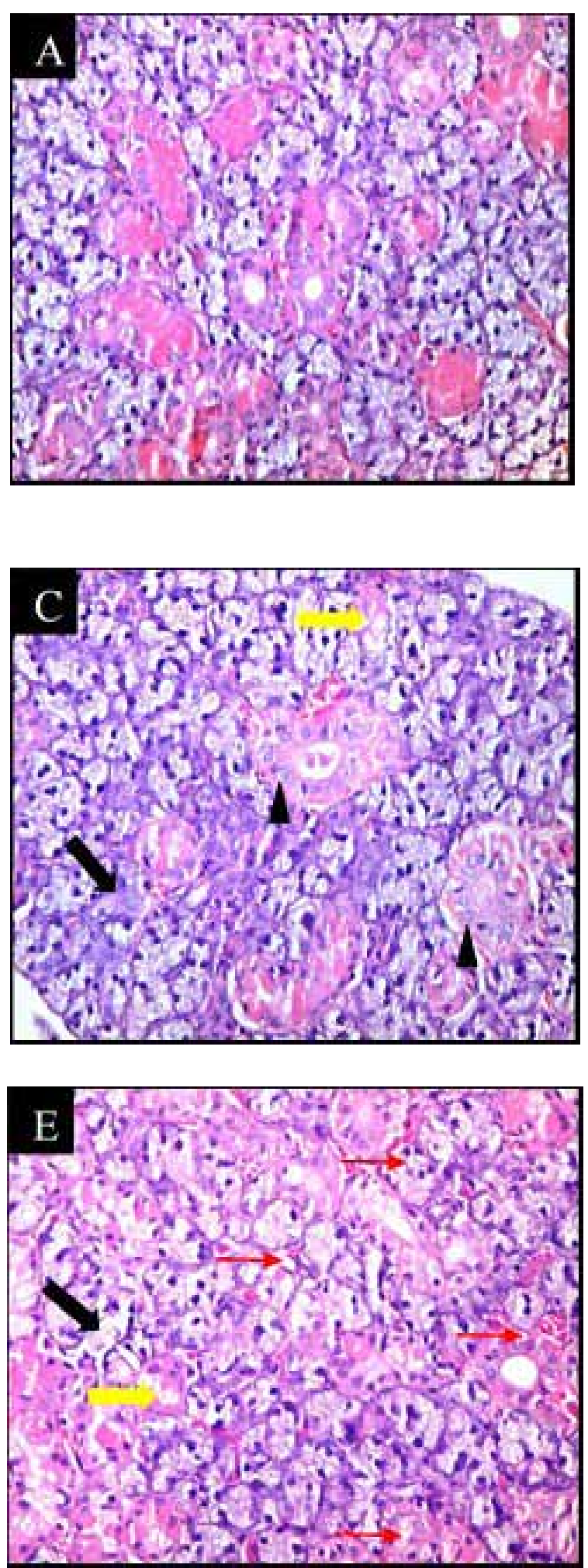

vacuolization and degeneration with nuclear fragmentation. The granular convoluted tubules showed nuclear fragmentation (Fig. 2 G).
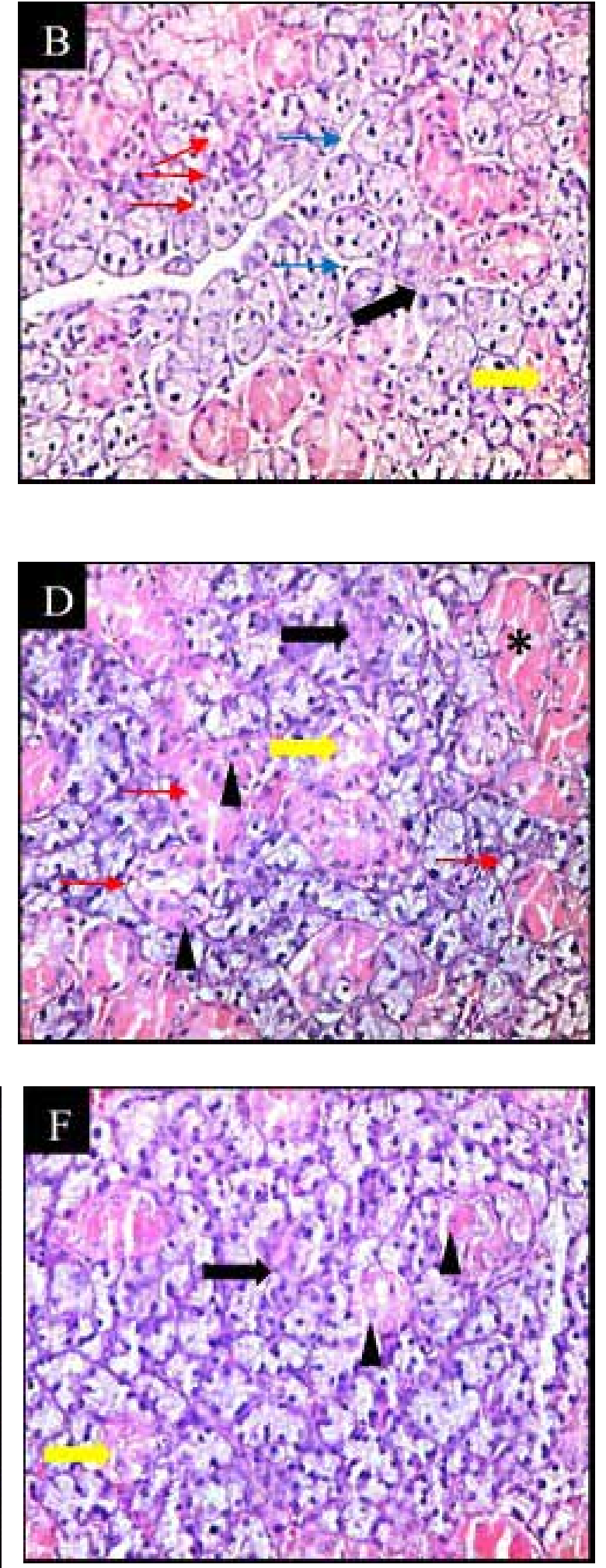

Egypt. J. Rad. Sci. Applic. 32, No.1 (2019) 


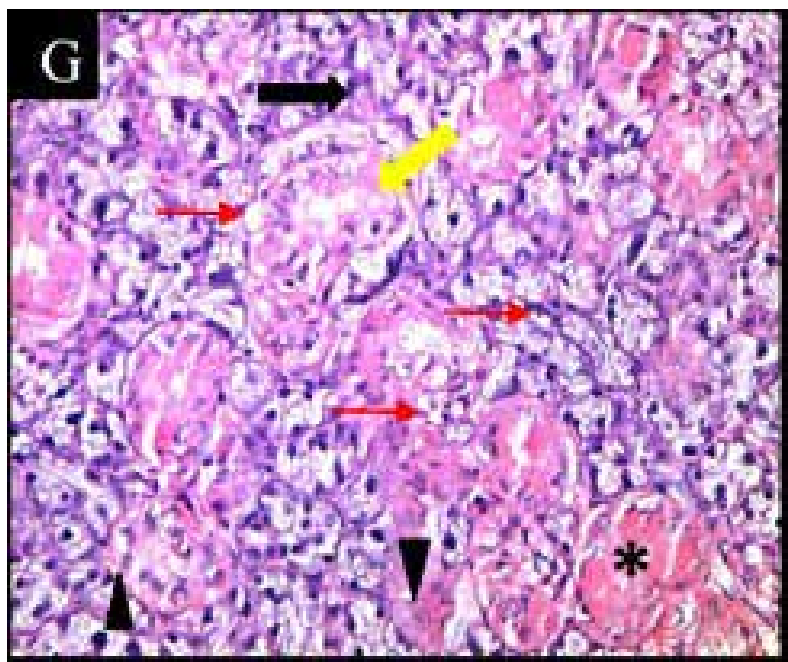

Fig. 2. Photomicrograph of the submandibular salivary glands of group $C(A)$, groups $R, P$ and $P R$ three days postirradiation, respectively $(\mathrm{B}, \mathrm{C}, \mathrm{D})$, groups $\mathrm{R}, \mathrm{P}$ and $\mathrm{PR}$ seven days post-irradiation, respectively $(\mathrm{E}, \mathrm{F}, \mathrm{G})$ showing slight acinar atrophy (blue arrows), loss of normal acinar outline (black arrows), vacuolization (red arrows), degenerated striated duct (yellow arrows), nuclear fragmentation (arrowheads) and degenerated granular convoluted tubules (asterisks) [H. \& E. x 400].

Biochemical analysis

The activity of GPx and SOD in submandibular gland tissues in addition to their content of GSH and protein in the different groups are presented in Table 1.

Three days post-irradiation, submandibular salivary glands GSH level in R, P and PR groups was significantly decreased when compared with $\mathrm{C}$ group. This condition extended to seven days post-irradiation except that GSH level of
P group was more or less similar to $\mathrm{C}$ group. When comparing $\mathrm{P}$ and $\mathrm{PR}$ groups to $\mathrm{R}$ group, the GSH level was significantly higher all over the experimental period. For GPx activity, all groups showed a significantly lower level of activity as compared to $\mathrm{C}$ group three and seven days post-irradiation. However, GPx activity in $\mathrm{P}$ and $\mathrm{PR}$ groups was a significantly higher when compared to $\mathrm{R}$ group both three and seven days-post irradiation.

TABLE 1. Total glutathione, glutathione peroxidase, superoxide dismutase and total protein content of submandibular glands of different groups all over the experimental period.

\begin{tabular}{cccccccc}
\hline \multicolumn{2}{c}{ GSH } & \multicolumn{2}{c}{ GPx } & SOD & Total protein \\
\hline Day 3 & Day 7 & Day 3 & Day 7 & Day 3 & Day 7 & Day 3 & Day 7 \\
\hline $68.2 \pm 0.8$ & $65.1 \pm 0.9$ & $122.3 \pm 1$ & $128.4 \pm 1$ & $4.8 \pm 0.3$ & $5.2 \pm 0.3$ & $86.3 \pm 0.8$ & $95.3 \pm 1$ \\
$35.7 \pm 1.2^{\mathrm{a}}$ & $21.6 \pm 0.8^{\mathrm{a}}$ & $75.2 \pm 0.9^{\mathrm{a}}$ & $64.9 \pm 0.9^{\mathrm{a}}$ & $2 \pm 0.2^{\mathrm{a}}$ & $3.1 \pm 0.3^{\mathrm{a}}$ & $52.9 \pm 1^{\mathrm{a}}$ & $41.6 \pm 0.8^{\mathrm{a}}$ \\
& & & & & & & \\
$49.8 \pm 1.4^{\mathrm{a}, \mathrm{b}}$ & $63.8 \pm 0.5^{\mathrm{b}}$ & $109.6 \pm 1^{\mathrm{a}, \mathrm{b}}$ & $119.2 \pm 0.7^{\mathrm{a}, \mathrm{b}}$ & $4.5 \pm 0.3^{\mathrm{b}}$ & $4.8 \pm 0.4^{\mathrm{b}}$ & $94.2 \pm 0.7^{\mathrm{a}, \mathrm{b}}$ & $93.4 \pm 0.5^{\mathrm{a}, \mathrm{b}}$ \\
& & & & & & & \\
$48.3 \pm 1.2^{\mathrm{a}, \mathrm{b}}$ & $59.2 \pm 1.1^{\mathrm{a}, \mathrm{b}}$ & $104.6 \pm 1.1^{\mathrm{a}, \mathrm{b}}$ & $113.5 \pm 0.8^{\mathrm{a}, \mathrm{b}}$ & $4.3 \pm 0.3^{\mathrm{b}}$ & $4.7 \pm 0.2^{\mathrm{b}}$ & $85.4 \pm 0.5^{\mathrm{b}}$ & $80.3 \pm 0.6^{\mathrm{a}, \mathrm{b}}$
\end{tabular}

${ }^{a}$ means significant difference as compared to $\mathrm{C}$ group and ${ }^{\mathrm{b}}$ means significant difference as compared to $\mathrm{R}$ group. 
The SOD activity in the submandibular glands was significantly decreased in group $\mathrm{R}$ compared to group C. Furthermore, its activity in groups $\mathrm{P}$ and $\mathrm{PR}$ was reduced in comparison to group $\mathrm{C}$, and these differences were statistically insignificant. At the same time, the previously mentioned levels of activity were significantly higher than those of group R. Regarding the total protein content. It is obvious that the irradiation group revealed a significantly lower content in comparison to the control group, three and seven days-post irradiation. Prednisolone treatment alone significantly increased the total protein content. The total protein content of group PR was similar to the control group three days postirradiation, but seven days post-irradiation, it was significantly lower. In comparison to group $\mathrm{R}$, the total protein contents of both $\mathrm{p}$ and $\mathrm{PR}$ groups were significantly higher.

\section{Discussion}

Ionizing radiation, as a therapeutic tool for treatment of head and neck tumors, induced free radicals generation and subsequent oxidative stress leading to morphological and functional alterations of many tissues among them salivary glands (Di Pietro et al., 2006). According to their highly differentiated cellular state the salivary glands should be radioresistant instead, they exhibit peculiar sensitivity to radiation (Grundmann et al., 2009).

The results of the present study demonstrated that gamma-irradiation of the rats induced cytoplasmic vacuoles in acinar, duct and granular convoluted tubules cells of submandibular glands. These changes were comparable to those demonstrated by Şimşek et al. (2012) and Sagowski et al. (2004). In addition, the acini showed outline loss with slight atrophy, the ducts and the granular convoluted tubules showed variable degrees of degeneration. This observation was in agreement with the findings of Gomes et al. (2013) and Ahlner et al. (1993). The acinar loss could be due to mast cell activation and release of their secretory molecules (Henriksson et al., 1994) and radiation induced apoptosis (Guchelaar et al., 1997). The reduced content of the granular convoluted tubules of the irradiated submandibular glands was also reported by Vissink et al. (1991). The serous acinar cells were demonstrated to be more sensitive to irradiation and these results are consistent with those observed by Nagler (2003) in the rats. The reduction of the irradiated submandibular gland weight detected in the present study was also reported by Medina et al. (2011). Analysis of gamma-irradiated submandibular glands revealed a reduced content of GSH, GPx, SOD and total protein content. Similar results were obtained by $\mathrm{Xu}$ et al. (2013) who found that Ionizing radiation caused a reduction of saliva secretion, salivary amylase activity, and superoxide dismutase and Şimşek et al. (2012) who reported a decreased GSH content of the irradiated submandibular and parotid glands.

Rats treated with prednisolone showed several morphological changes of their submandibular glands including loss of acinar architecture and out line with shrinkage of some acini. The striated ducts revealed variable degenerative changes, decreased size with space surrounding them, narrowing of the lumen that extend to complete obliteration. The granular convoluted tubules expressed degenerative changes. The nuclei of the striated ducts and granular convoluted tubules showed nuclear fragmentation. Similar results were obtained by Taher (2008) who found that the acini of submandibular glands of cortisol treated mice represented lost foamy appearance, shrinkage with irregular shape and an ill-defined cellular outline. He added that striated ducts revealed atrophy and shrinkage of the ductal cells with the presence of large space around all striated ducts. In the present study, prednisolone treatment associated with a decreased GSH content and GPx activity, while the SOD activity was not affected, but the total protein content was increased. Similarly, McIntosh et al. (1998 b) found that glucocorticoid treatment significantly decreased GPx activity. For $\mathrm{Cu} / \mathrm{Zn}$ SOD activity, it was significantly lower in brain, but higher in the liver while, Mn SOD activity was unaffected by treatment. They suggested that glucocorticoid may lower the antioxidant capacity of tissues in a region-specific manner. El-Halwagy et al. (2016) found that the use of the therapeutic dose of anabolic androgenic steroid significantly reduced the GSH content and increased total protein content of the liver while the SOD activity was not affected.

\section{Conclusion}

Gamma-irradiation or prednisolone treatment alone markedly affected the submandibular 
salivary gland structure. Their effects on salivary gland antioxidant status and total protein content were different. However, their combined use ameliorated, to some extent, gamma radiation induced oxidative damage.

\section{Disclosure of interest}

The author reports no conflicts of interests.

\section{References}

Adelstein, D.J., Lavertu, P., Saxton, J.P., Secic, M., Wood, B.G., Wanamaker, J.R. and Larto, M.A. (2000) Mature results of a phase III randomized trial comparing concurrent chemoradiotherapy with radiation therapy alone in patients with stage III and IV squamous cell carcinoma of the head and neck. Cancer, 88(4), 876-883.

Ahlner, B.H., Hagelqvist, E., Lind, M.G. and Rudén, B.I. (1993) Irradiation of rabbit submandibular glands histology and morphometry after 15 Gy. Acta Otolaryngol. 113(2), 210-219.

Atkinson, J.C. and Wu, A.J. (1994) Salivary gland dysfunction: Causes, symptoms, treatment. J. Am. Dent. Assoc. 125(4), 409-416.

Bazsó, A., Szappanos, Á., Patócs, A., Poór, G., Shoenfeld, Y. and Kiss, E. (2015) The importance of glucocorticoid receptors in systemic lupus erythematous. A systematic review. Trends Endocrinol. Metab. 24(3), 109-119.

Beutler, E. (1963) Improved method for determination of blood glutathione. J. Lab. Clin. Med. 61(5), 882888.

Busillo, J.M. and Cidlowski, J.A. (2013) The five Rs of glucocorticoid action during inflammation: ready, reinforce, repress, resolve, and restore. Trends Endocrinol. Metab. 24(3), 109-119.

Di Pietro, C., Piro, S., Tabbi, G., Ragusa, M., Di Pietro, V., Zimmitti, V., Cuda, F., Anello, M., Consoli, U., Salinaro, E.T., Caruso, M., Vancheri, C., Crimi, N., Sabini, M.G., Cirrone, G.A., Raffaele, L., Privitera, G., Pulvirenti, A., Giugno, R., Ferro, A., Cuttone, G., Lo Nigro, S., Purrello, R., Purrello, F. and Purrello, M. (2006) Cellular and molecular effects of protons: Apoptosis induction and potential implications for cancer therapy. Apoptosis, 11(1), 57-66.
El-Halwagy, M.E., Abd-Alrahman, S.H., Mahmoud, R.H., Khalifa, F.K., Darwish, N.S., Attia, A.A. and Mohamed, A.S. (2016) Impact of chronic and rogenic steroid exposure on liver toxicity. Int. J. Clin. Exp. Pathol. 9(2), 2652-2659.

Gomes, C.C., Ramos-Perez, F.M.D.M., Perez, D.E.D.C., Novaes, P.D., Boscolo, F.N. and Almeida, S.M.D. (2013) Radioprotective effect of vitamin E in parotid glands: a morphometric analysis in rats. Braz. Dent. J. 24(3), 183-187.

Goodman, Y., Bruce, A.J., Cheng, B. and Mattson, M.P. (1996) Estrogens attenuate and corticosterone exacerbates excitotoxicity, oxidative injury and amyloid $\beta$-Peptide toxicity in hippocampal neurons. J. Neurochem. 66(5), 1836-1844.

Grundmann, O., Mitchell, G.C. and Limesand, K.H. (2009) Sensitivity of salivary glands to radiation: from animal models to therapies. J. Dent. Res. 88(10), 894-903.

Guchelaar, H.J., Vermes, A. and Meerwaldt, J.H. (1997) Radiation-induced xerostomia: Pathophysiology, clinical course and supportive treatment. Suppor. Care Cancer, 5(4), 281-288.

Henriksson, R., Fröjd, Ö., Gustafsson, H., Johansson, S., Yi-Qing, C., Franzen, L. and Bjermer, L. (1994) Increase in mast cells and hyaluronic acid correlates to radiation-induced damage and loss of serous acinar cells in salivary glands: The parotid and submandibular glands differ in radiation sensitivity. Br. J. Cancer, 69(2), 320-326.

Henry, R.J. (1974) "Clinical Chemistry, Principles and

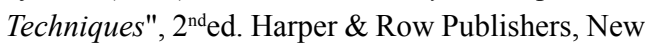
York.

McIntosh, L.J. and Sapolsky, R.M. (1996) Glucocorticoids increase the accumulation of reactive oxygen species and enhance adriamycininduced toxicity in neuronal culture. Exp. Neurol. 141(2), 201-206.

McIntosh, L.J., Cortopassi, K.M. and Sapolsky, R.M. (1998 a) Glucocorticoids may alter antioxidant enzyme capacity in the brain: kainic acid studies. Brain Res. 791(1-2), 215-222.

McIntosh, L.J., Hong, K.E. and Sapolsky, R.M. (1998 b) Glucocorticoids may alter antioxidant enzyme 
capacity in the brain: Baseline studies. Brain Res. 791(1-2), 209-214.

Medina, V.A., Prestifilippo, J.P., Croci, M., Carabajal, E., Bergoc, R.M., Elverdin, J.C. and Rivera, E.S. (2011) Histamine prevents functional and morphological alterations of submandibular glands induced by ionising radiation. Int. J. Radiat. Biol. 87(3), 284-292.

Nagler, R.M. (2003) Effects of head and neck radiotherapy on major salivary glands-animal studies and human implications. In Vivo, 17(4), 369-375.

Nederfors, T. (1996) Xerostomia: Prevalence and pharmacotherapy with special reference to betaadrenoceptor antagonists. Swed. Dent. J. Suppl. 116, 1-70.

Nishikimi, M., Rao, N.A. and Yagi, K. (1972) The occurrence of superoxide anion in the reaction of reduced phenazinemethosulfate and molecular oxygen. Biochem. Biophys. Res. Commun. 46(2), 849-854.

O'Connell, A.C., Redman, R.S., Evans, R.L. and Ambudkar, I.S. (1999) Radiation-induced progressive decrease in fluid secretion in rat submandibular glands is related to decreased acinar volume and not impaired calcium signaling. Radiat. Res. 151(2), 150-158.

Rotruck, J.T., Pope, A.L., Ganther, H.E., Swanson, A.B., Hafeman, D.G. and Hoekstra, W. (1973) Selenium: Biochemical role as a component of glutathione peroxidase. Science, 179(4073), 588590.

Sagowski, C., Wenzel, S., Riehle, I., Tesche, S., Jenicke, L., Zywietz, F., Roeser, K. and Metternich,
F.U. (2004) Histomorphologic and salivary gland scintigraphic findings in radiation-induced sialadenitis due to fractionated irradiation of the head and neck region of rats. A model for evaluating potentially radioprotective substances. $H N O, \mathbf{5 2}(1)$, 25-32.

Schäcke, H., Döcke, W.D. and Asadullah, K. (2002) Mechanisms involved in the side effects of glucocorticoids. Pharmacol. Ther. 96(1), 23-43.

Şimşek, G., Gürocak, Ş., Karadağ, N., Karabulut, A.B., Demirtaş, E., Karataş, E. and Pepele, E. (2012) Protective effects of resveratrol on salivary gland damage induced by total body irradiation in rats. Laryngoscope, 122(12), 2743-2748.

Stone, H.B., Coleman, C.N., Anscher, M.S. and McBride, W.H. (2003) Effects of radiation on normal tissue: Consequences and mechanisms. Lancet Oncol. 4(9), 529-536.

Taher, M.T. (2008) Effect of cortisol on submandibular salivary gland. Med. J. Tikrit, 1(141), 165-168.

Vissink, A., Kalicharan, D., S-Gravenmade, E.J., Jongebloed, W.L., Ligeon, E.E., Nieuwenhuis, P. and Konings, A.W.T. (1991) Acute irradiation effects on morphology and function of rat submandibular glands. J. Oral Pathol. Med. 20(9), 449-456.

Xu, L., Yang, X., Cai, J., Ma, J., Cheng, H., Zhao, K., Yang, L., Cao, Y., Qin, Q., Zhang, C. and Zhang, Q. (2013) Resveratrol attenuates radiation-induced salivary gland dysfunction in mice. Laryngoscope, 123(11), E23-E29.

(Received 4/7/2018,

accepted 3/3 /2019) 


\section{دراسة مقارنة للضرر التأكسدى للغذة تحت الفك السفلى الناتج عن أشعة جاماو البريدنيزولون \\ سلوى فريد أحمد \\ قسم البحوث الصحية الإشعاعية ـ المركز القومى لبحوث وتكنولوجيا الإشعاع ـ هيئة الطاقة الذرية ـ القاهرة ـ}

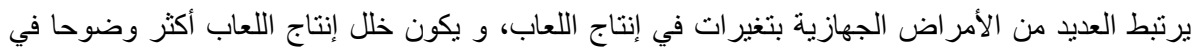

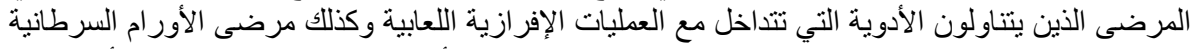

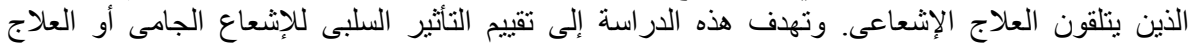

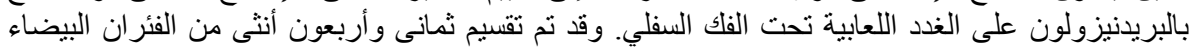

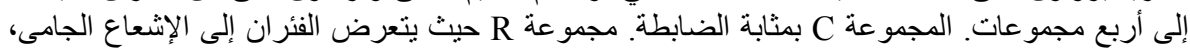

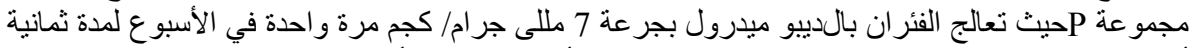

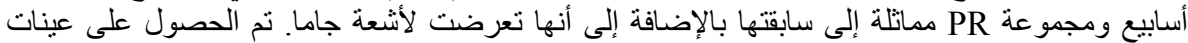

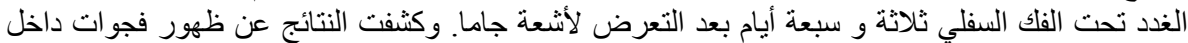

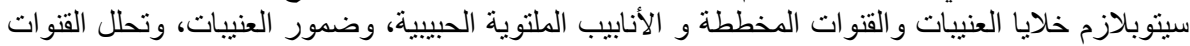

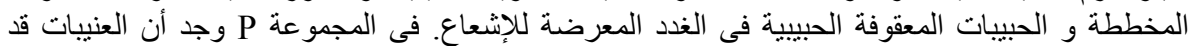

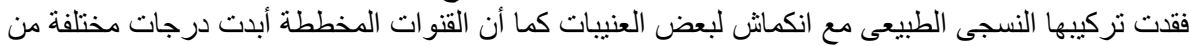

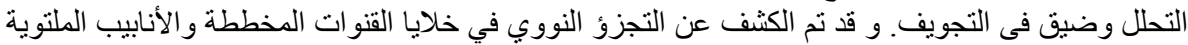

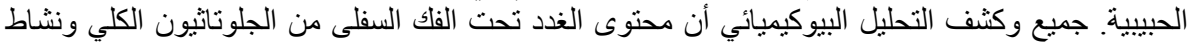

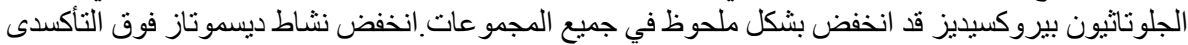

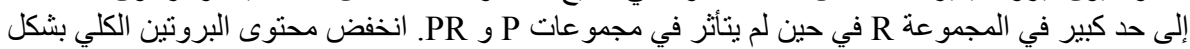

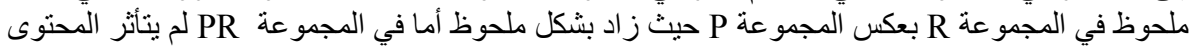

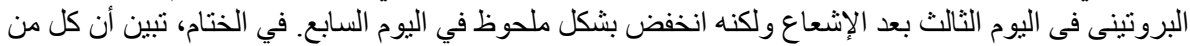

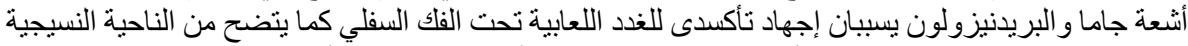
و البيوكيميائية ولكن استخدامهما معا أدى إلى تحسن الإجهاد التأكسدى الناتج عن أنشعة جاما. ما سبق من مظ مناهر

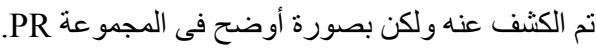

وكثنف التحليل البيوكيميائي أن محتوى الغدد تحت الفك السفلى من الجلوتاثيون الكلي ونشاط الجلوتاثيون

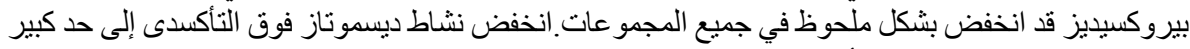

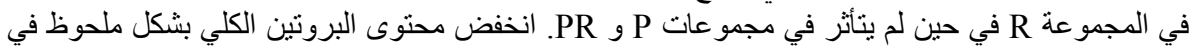

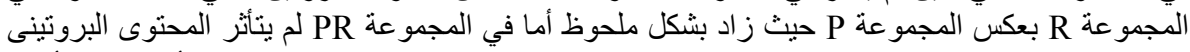

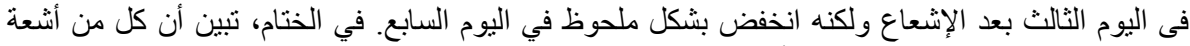

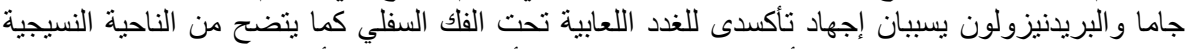
و البيو كيميائية ولكن استخدامهما معا أدى إلى تحسن الإجهاد التأكسدى الناتج عن أشعة جاما. 